\title{
Yellow Mombin (Spondias mombin L.) Seeds from Agro-Industrial Waste as a Novel Adsorbent for Removal of Hexavalent Chromium from Aqueous Solutions
}

\author{
Adilson S. Santos, ${ }^{\oplus a}$ Tereza S. M. Santos, ${ }^{\oplus b}$ Valfredo A. Lemos ${ }^{\oplus a}$ and \\ Alexilda O. de Souza $*$ *a \\ aPrograma de Pós-Graduação em Química, Universidade Estadual do Sudoeste da Bahia, \\ Campus Juvino Oliveira, 45700-000 Itapetinga-BA, Brazil

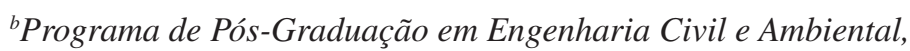 \\ Universidade Estadual de Feira de Santana, Av. Transnordestina, s/n, Novo Horizonte, \\ 44036-900 Feira de Santana-BA, Brazil
}

\begin{abstract}
The objective of this study was to develop a low-cost and eco-friendly adsorbent from agroindustrial waste for the removal of hexavalent chromium in the aqueous medium. The adsorbent (BMC) produced from yellow mombin (Spondias mombin L.) seeds was characterized by the determination of the chemical composition, thermal analysis (thermogravimetric (TG) analysis and differential thermal analysis (DTA)), Fourier transform infrared spectroscopy (FTIR), pH in suspension and determination of the point of zero charge (PZC). The presence of proteins, fats and carbohydrates $(15.690,1.004$, and $73.706 \%$, respectively) suggests that the material can be a promising adsorbent, given the availability of functional groups. The following conditions were set: $\mathrm{pH} 2.0$, adsorbent mass $450 \mathrm{mg}$, and equilibrium was reached after $80 \mathrm{~min}$. The maximum adsorption capacity was approximately $98 \%$. Kinetic studies showed that the pseudo-second-order kinetic equation was the one that best adjusted to the experimental data. Under the conditions investigated, the Langmuir isotherm model described the best balance data, signaling the adsorption in monolayer. According to the results, it was found that the BMC showed an outstanding performance for the removal of $\mathrm{Cr}^{\mathrm{VI}}$ ions and may become a viable and efficient alternative for the treatment of industrial effluents containing trace elements.
\end{abstract}

Keywords: biomass, agro-industrial waste, adsorbent, trace elements

\section{Introduction}

The pollution of water resources is a serious environmental problem associated with increased industrial and agricultural activity. Such activities generate toxic compounds of various classes and in large quantities which, in many cases, are inappropriately discarded in the environment. ${ }^{1,2}$ Various industrial processes developed in the sectors of mining, fertilizers, fuel production, paint, pigments, metal plating, tanning, paper, pulp, leather, electroplating, textiles and chemicals, can cause negative environmental impacts when by-products and effluents from their processes are improperly disposed, especially in wastewaters. ${ }^{1-4}$

Trace elements present in their chemical processes such as lead, copper, nickel, arsenic and chromium present high toxicity and bioaccumulation, and can pose incalculable risks to human health, as well as intensify environmental

*e-mail: alexilda@uesb.edu.br problems through the deterioration of fauna and flora. ${ }^{3,5,6}$ Several diseases and physiological disorders are reported in the literature ${ }^{3,7-12}$ by the dissemination of these elements.

Due to its toxicity, chromium is considered one of the most toxic metals and is on the priority pollutant list, as defined by the US Environmental Protection Agency (EPA), which establishes a maximum limit of total chromium in drinking water of $50 \mu \mathrm{g} \mathrm{L}{ }^{-1},{ }^{13}$ as a function of its mutagenic and carcinogenic properties. ${ }^{711}$ Chromium toxicity depends on the valence state. In aqueous solutions, chromium occurs more frequently as $\mathrm{Cr}^{\mathrm{III}}$ and $\mathrm{Cr}^{\mathrm{VI}} .{ }^{14} \mathrm{Chromium}(\mathrm{VI})$ has significantly higher toxicity levels than other valence states $^{15}$ due to its high mobility and water solubility, ${ }^{10}$ in addition to being easily absorbed by the body. ${ }^{16}$ The chemistry of $\mathrm{Cr}^{\mathrm{VI}}$ is very dependent on $\mathrm{pH}$. Table 1 reports the predominant species at each $\mathrm{pH}$ range. ${ }^{9}$

Several conventional methodologies are frequently used to treat areas contaminated with trace elements: chemical and electrochemical precipitation, ${ }^{17-20}$ chemical oxidation 
Table 1. Composition of the $\mathrm{Cr}^{\mathrm{VI}}$ solution as a function of $\mathrm{pH}$

\begin{tabular}{lc}
\hline $\mathrm{pH}$ & Predominant species \\
\hline$<1$ & $\mathrm{H}_{2} \mathrm{CrO}_{4}$ (chromic acid) \\
$2-4$ & $\mathrm{Cr}_{2} \mathrm{O}_{7}^{2-}$ (dichromate) \\
$4-6$ & $\mathrm{HCrO}_{4}^{-}$(hydrogen chromate) $\mathrm{Cr}_{2} \mathrm{O}_{7}^{2-}$ (dichromate) \\
$6-8$ & $\mathrm{Cr}_{2} \mathrm{O}_{7}^{2-}($ dichromate $), \mathrm{CrO}_{4}{ }^{2-}$ (chromate) \\
$>8$ & $\mathrm{CrO}_{4}{ }^{2-}$ (chromate) \\
\hline
\end{tabular}

and reduction, ${ }^{19,21}$ filtration, ${ }^{19,21}$ ion exchange, ${ }^{18,19,21,22}$ electrochemical treatment, ${ }^{17,19}$ reverse osmosis ${ }^{22}$ and flotation. ${ }^{18}$ However, these methods have demonstrated several disadvantages that make their use in large scale unfeasible. Among the main drawbacks are the incomplete metal removal, sensitive operating conditions, low efficiency, culminating in the generation of toxic waste or other products that require treatment. ${ }^{1,19}$ The adsorption process is considered promising for the removal of heavy metals from aqueous solutions using different adsorbent materials, as it has important advantages, such as high efficiency, low cost, minimization of chemical and biological sludge, no additional nutrient required, regeneration of the adsorbent and possibility of metal recovery. ${ }^{4,23}$

The adsorption process is a phenomenon that mainly involves the use of surface forces. Alternatively, it can be defined as any division of chemical species between the primary phase and an interface or the accumulation of substances near the interface. ${ }^{24}$ Agro-industrial waste has aroused considerable interest, once they consist of lignin, cellulose, hemicellulose, lipids, proteins, sugars, water, lignocellulosic substrate and many other compounds possessing a great variety of functional groups, ${ }^{11,25-27}$ and these residues are the most abundant lignocellulosic raw materials in nature. ${ }^{28} \mathrm{~A}$ variety of agricultural residues have already been evaluated in heavy metal adsorption processes, such as $\mathrm{Cd}^{\mathrm{II}}, \mathrm{Cu}^{\mathrm{II}}, \mathrm{Cr}^{\mathrm{III}}, \mathrm{Cr}^{\mathrm{VI}}, \mathrm{Pb}^{\mathrm{II}}, \mathrm{Hg}^{\mathrm{II}}, \mathrm{Zn}^{\mathrm{II}}$, etc., showing good performance. ${ }^{1,29-33}$

The proposal of this study was to use yellow mombin (Spondias mombin L.) seeds, from the fruit processing in the agroindustry, to produce a new adsorbent and to apply it in the removal of hexavalent chromium in an aqueous medium. The processing of these fruits to produce pulp, juice, sweets and other products, generates high amounts of waste, formed mainly by seeds, which are normally discarded in the environment without any treatment. The use of these residues to produce natural adsorbent, without any chemical or physical treatment that requires financial investment, will add value to the waste and reduce the environmental impacts caused by inadequate disposal, in addition to contributing to the treatment of wastewater contaminated with trace elements.

\section{Experimental}

\section{Material and methods}

A $1000 \mathrm{mg} \mathrm{L}^{-1} \mathrm{Cr}^{\mathrm{VI}}$ standard solution (Sigma-Aldrich, St. Louis, USA) was used for the preparation of all chromium solutions used in the experiments. All procedures were performed at room temperature $\left(27 \pm 2^{\circ} \mathrm{C}\right)$. The $\mathrm{pH}$ of the solution was adjusted with solutions of $\mathrm{NaOH}$ (PA, Vetec, Rio de Janeiro, Brazil) and $\mathrm{HCl}$ (37\%, Synth, São Paulo, SP, Brazil), both at a concentration of $0.1 \mathrm{~mol} \mathrm{~L}^{-1}$ and, for comparison, the most significant points in the $\mathrm{pH}$ study were repeated by adjusting with $1.0 \mathrm{~mol} \mathrm{~L}^{-1} \mathrm{KCl}$ (Synth, São Paulo, SP, Brazil)/HCl solution.

\section{Obtention and characterization of the adsorbent}

The yellow mombin fruit waste was supplied by a pulp company located in the southwest region of Bahia, Brazil. The fruit residue includes seeds and shell. The shells and pulp fragments were discarded. The still moist residues were taken to the laboratory and then washed with deionized water to separate the seeds and dried at the sun, then sieved for complete removal of pulp residues.

After the previous step, the material was dried in a stove (Marconi, model MA 120, São Paulo, SP, Brazil) with air circulation for $24 \mathrm{~h}$ and ground in a 2-mm knife mill. For the adsorption tests, the residue was sieved to obtain a smaller particle size, using an 18-mesh standard screen. The acronym BMC used in the text refers to the term "biosorbent from yellow mombin fruit seeds".

The BMC was characterized by several techniques, such as: determination of the chemical composition, ${ }^{34,35}$ obtaining spectra by Fourier transform infrared (FTIR) spectroscopy in the range of 4000 to $450 \mathrm{~cm}^{-1}$ using a spectrometer (PerkinElmer, Spectrum UATR TWO, Massachusetts, USA) and obtaining thermogravimetric (TG, Shimadzu, TGA-50, Kyoto, Japan) and differential thermal analysis (DTA, Shimadzu, Thermobalance DTG 60-A, Kyoto, Japan) curves from 25 to $1000{ }^{\circ} \mathrm{C}$. The point of zero charge (PZC) was measured using the methodology called " 11 point experiment" 36 and the suspended $\mathrm{pH}$ of $\mathrm{BMC}$ was determined following the literature. ${ }^{37}$

\section{Determination of the adsorption capacity of BMC}

The adsorption experiments were performed in triplicate to estimate the BMC adsorption capacity and the errors of the experimental measurements were evaluated by the standard deviation calculation. Thus, appropriate masses of the BMC were weighed directly into $50 \mathrm{~mL}$ test tubes, and 
$25 \mathrm{~mL}$ of the $\mathrm{Cr}^{\mathrm{VI}}$ solution at a concentration of $50 \mathrm{mg} \mathrm{L}^{-1}$ with pre-adjusted $\mathrm{pH}$ was then added to the respective tubes. All tubes were brought to a shaker at room temperature. The adsorption capacity of the biosorbent, $\mathrm{Q}_{\mathrm{e}}$ ( $\mathrm{mg}$ of metal per $\mathrm{g}$ of BMC) was determined using equation $1: 38$

$\mathrm{Q}_{\mathrm{e}}=\frac{\left(\mathrm{C}_{\mathrm{o}}-\mathrm{C}_{\mathrm{e}}\right)}{\mathrm{m}} \mathrm{V}$

where, $\mathrm{C}_{\mathrm{o}}$ and $\mathrm{C}_{\mathrm{e}}\left(\mathrm{mg} \mathrm{L}^{-1}\right)$ are the initial and final concentrations of the $\mathrm{Cr}^{\mathrm{VI}}$ solution, respectively; $\mathrm{m}(\mathrm{g})$ is the amount of adsorbent, and $\mathrm{V}(\mathrm{L})$ is the volume of the $\mathrm{Cr}^{\mathrm{VI}}$ solution. The capacity of $\mathrm{Cr}^{\mathrm{VI}}$ removal by the adsorbent can also be expressed in terms of percentage, according to equation $2: 11,39$

$\operatorname{Removal}(\%)=\frac{\left(\mathrm{C}_{\mathrm{o}}-\mathrm{C}_{\mathrm{e}}\right)}{\mathrm{C}_{\mathrm{o}}} \times 100$

The quantification of $\mathrm{Cr}^{\mathrm{VI}}$ in the supernatant solution was performed by using a flame atomic absorption spectrometer (PerkinElmer, AAnalyst 200, Massachusetts, USA).

Adsorption tests: optimization of experimental parameters

Effect of adsorbent mass on the adsorption of $\mathrm{Cr}^{\mathrm{vI}}$

The study of adsorbent mass was carried out through the addition of different quantities of BMC. The following masses were investigated: $0.0500 ; 0.1000 ; 0.2000 ; 0.3000$; $0.4000 ; 0.5000 ; 0.6000$ and $0.7000 \mathrm{~g}$. Thus, the respective masses were weighed on an analytical balance directly into the test tubes, and $25 \mathrm{~mL}$ of the $50 \mathrm{mg} \mathrm{L}^{-1}$ metal solution was then added. The $\mathrm{pH}$ of the solution was adjusted to 2.44 by the addition of small amounts of $\mathrm{NaOH}$ and $\mathrm{HCl}$, both at a concentration of $0.1 \mathrm{~mol} \mathrm{~L}^{-1}$. Subsequently, the tubes were agitated in an orbital table and the solution was in contact with the adsorbents for $1 \mathrm{~h}$. After this time, the solutions were filtered and immediately quantified for the concentration of chromium in the supernatant solution by flame atomic absorption spectrometry (FAAS).

\section{Effect of $\mathrm{pH}$ on $\mathrm{Cr}^{\mathrm{v}}$ adsorption}

From the mass that resulted in the best adsorption results in the previous step, the assays were repeated by varying the $\mathrm{pH}$ of the solution, monitoring with the aid of a digital pHmeter (Quimis, G 400 AS, São Paulo, SP, Brazil). The pH was adjusted with the $\mathrm{NaOH}$ and $\mathrm{HCl}$ solutions described above. The investigated $\mathrm{pH}$ values were: $1.0 ; 1.5 ; 2.0 ; 3.0$; $4.0 ; 6.0 ; 7.0 ; 8.0$ and 10 . At each $\mathrm{pH}$, the solution remained in contact with the BMC for $1 \mathrm{~h}$, and measurements were then made by FAAS to observe the adsorbed mass at each step of the analysis. For comparison purposes, the most important $\mathrm{pH}$ values for the study $(1.5,2.0$, and 3.0$)$ were repeated with the adjustment with $1.0 \mathrm{~mol} \mathrm{~L}^{-1} \mathrm{KCl} / \mathrm{HCl}$ solution.

\section{Adsorption studies}

After the optimization of the previous parameters, the time necessary to reach the adsorption equilibrium was also investigated. The solutions containing the adsorbents remained under stirring at room temperature in periods of $10 ; 20 ; 30 ; 40 ; 60 ; 80 ; 100 ; 120 ; 140 ; 160$ and $180 \mathrm{~min}$. At each time interval, measurements were performed by FAAS. The purpose of this study was to determine the time required for the two phases (adsorbent/adsorbate) to reach equilibrium.

The kinetic data were fitted to the following non-linear kinetic models: pseudo-first-order, pseudo-second-order, and Elovich, according to the equations described in Table 2.

The adsorption isotherm is essential to understand how the adsorbent interacts with the adsorbate, not only to give an idea of its adsorption capacity, but also playing a vital role in understanding the adsorption mechanism. The isotherms were adjusted using the Langmuir, Freundlich, and Redlich-Peterson nonlinear models, which are described in Table 3.

Table 2. Some adsorption kinetic models

\begin{tabular}{|c|c|c|c|}
\hline Name & Model & Linear form & Reference \\
\hline Lagergren pseudo first-order model & $\frac{\mathrm{dQ}}{\mathrm{dt}}=\mathrm{K}_{1}\left(\mathrm{Q}_{\mathrm{e}}-\mathrm{Q}_{\mathrm{t}}\right)$ & $\log \left(Q_{e}-Q_{t}\right)=\log Q_{e}-\frac{K_{1}}{2,303} t$ & 40 \\
\hline Pseudo-second order model & $\frac{\mathrm{dQ}_{\mathrm{t}}}{\mathrm{dt}}=\mathrm{K}_{2}\left(\mathrm{Q}_{\mathrm{e}}-\mathrm{Q}_{\mathrm{t}}\right)^{2}$ & $\frac{t}{Q_{t}}=\frac{1}{K_{2} Q_{e}^{2}}+\frac{t}{Q_{e}}$ & 41 \\
\hline Elovich & $\frac{\mathrm{dQ}_{\mathrm{t}}}{\mathrm{dt}}=\alpha \exp \left(-\beta \mathrm{q}_{\mathrm{t}}\right)$ & $\mathrm{q}_{\mathrm{t}}=\beta \ln (\alpha \beta)+\beta \ln \mathrm{t}$ & 42 \\
\hline
\end{tabular}

$\mathrm{Q}_{\mathrm{e}}$ and $\mathrm{Q}_{\mathrm{t}}$ : adsorption capacities at equilibrium and at time $\mathrm{t}$, respectively; $\mathrm{K}_{1}:$ pseudo-first-order adsorption rate constant; $\mathrm{K}_{2}$ : pseudo-second-order adsorption rate constant; $\mathrm{q}_{\mathrm{t}}$ : adsorbed amount at time $\mathrm{t} ; \alpha$ and $\beta$ : constants during an experiment. 
Table 3. Different isotherm models

\begin{tabular}{lcc}
\hline Name & Model & Linear form \\
\hline Langmuir & $\mathrm{q}_{\mathrm{e}}=\frac{\mathrm{Q}^{\circ} \mathrm{b} \mathrm{C}_{\mathrm{e}}}{1+\mathrm{b} \mathrm{C}_{\mathrm{e}}}$ & $\frac{\mathrm{C}_{\mathrm{e}}}{\mathrm{q}_{\mathrm{e}}}=\frac{1}{\mathrm{Q}^{\circ} \mathrm{b}}+\frac{1}{\mathrm{Q}^{\circ}} \mathrm{C}_{\mathrm{e}}$ \\
Freundlich & $\mathrm{q}_{\mathrm{e}}=\mathrm{K}_{\mathrm{F}} \mathrm{C}_{\mathrm{e}}^{1 / \mathrm{n}}$ & $\log \mathrm{q}_{\mathrm{e}}=\log \mathrm{K}_{\mathrm{F}}+\frac{1}{\mathrm{n}} \log \mathrm{C}_{\mathrm{e}}$ \\
Redlich-Peterson & $\mathrm{q}_{\mathrm{e}}=\frac{\mathrm{K}_{\mathrm{R}} \mathrm{C}_{\mathrm{e}}}{1+\mathrm{a}_{\mathrm{R}} \mathrm{C}_{\mathrm{e}}^{\mathrm{g}}}$ & $\log \left(\mathrm{K}_{\mathrm{R}} \frac{\mathrm{C}_{\mathrm{e}}}{\mathrm{q}_{\mathrm{e}}}-1\right)=\log \left(\mathrm{a}_{\mathrm{R}}\right)+\alpha \log \left(\mathrm{C}_{\mathrm{e}}\right)$ \\
\hline
\end{tabular}

$\mathrm{q}_{\mathrm{e}}$ : amount of solute adsorbed per unit mass of the adsorbent; $\mathrm{C}_{\mathrm{e}}$ : equilibrium concentration of the adsorbate; $\mathrm{Q}^{\circ}$ : adsorption capacity of the monolayer; $\mathrm{b}$ : constant related to the free energy of adsorption; $\mathrm{K}_{\mathrm{F}}$ : Freundlich isotherm constant; $\mathrm{K}_{\mathrm{R}}$ and $\mathrm{a}_{\mathrm{R}}$ : Redlich-Peterson isotherm constants; $\alpha$ : Redlich-Peterson isotherm exponent; $\mathrm{n}$ : constant indicative of the intensity of adsorption.

Adjustments to mathematical models for both kinetic studies and equilibrium data were assessed statistically by correlation coefficient $\left(\mathrm{R}^{2}\right)$ and $\left(\chi^{2}\right)$ Chi-square statistic test; the error functions sum of squared errors (SSE); average relative error (ARE) and hybrid fractional error function (HYBRID) were considered for adsorption isotherms. ${ }^{27}$

Effect of the initial concentration of the metal solution

The concentration of the initial metal solution was also determined. Thus, $25 \mathrm{~mL}$ of the $\mathrm{Cr}^{\mathrm{VI}}$ solution at $\mathrm{pH} 2.0$ were added to the mass adopted at the following concentrations: $10 ; 20 ; 50 ; 80 ; 100 ; 150 ; 200 ; 250$ and $350 \mathrm{mg} \mathrm{L}^{-1}$. The time the BMC came into contact with the solution was obtained in the previous procedure.

\section{Results and Discussion}

\section{Characterization of BMC}

\section{Chemical composition}

According to the chemical composition results, humidity and ash contents were found to be low (9.150 and $0.450 \%$, respectively). The presence of proteins, fats and carbohydrates (15.690, 1.004, and $73.706 \%$, respectively) suggests that the material may be a suitable adsorbent, considering the availability of critical functional groups such as carboxylates and hydroxyls. These functional groups can cause weak van der Waals interparticle bonds between the $\mathrm{Cr}^{\mathrm{VI}}$ solution species and the adsorbent.

\section{Fourier transform infrared spectroscopy (FTIR)}

The FTIR spectrum obtained for the BMC before and after the metal adsorption process is shown in Figure 1.

The FTIR spectrum before the process was essential to identify the major functional groups present on the surface of the biomass. A broad band centered around $3300 \mathrm{~cm}^{-1}$ can be assigned to stretches of the $\mathrm{OH}$ (alcohol, phenol and carboxylic acid) bond due to inter- and intramolecular

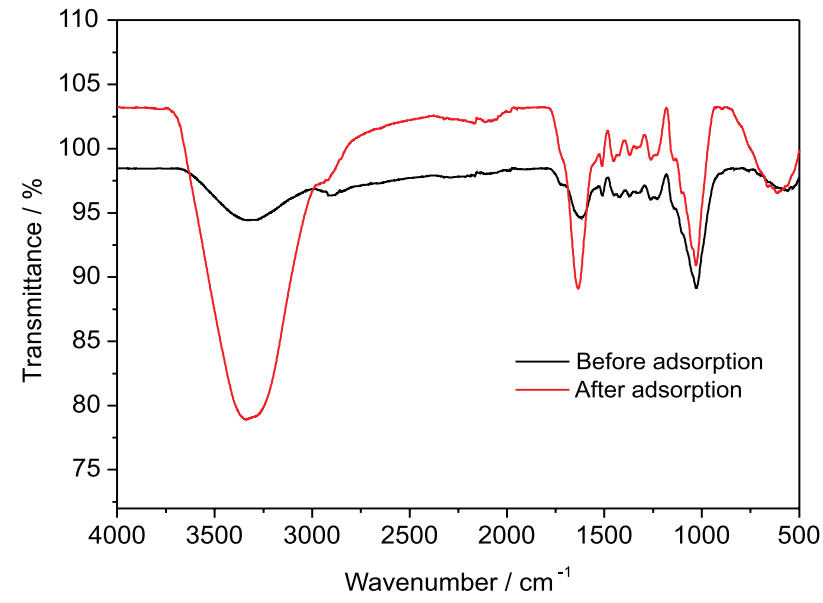

Figure 1. FTIR spectra before and after $\mathrm{Cr}^{\mathrm{VI}}$ biosorption.

interactions, as a consequence of deformations of hydrogen bonds and/or NH stretches and the presence of amino groups, ${ }^{7,10,18}$ in view of the presence of proteins in the chemical composition of BMC. This band can also be assigned to the intermolecular stretches of $\mathrm{O}-\mathrm{H}$ bonds from the cellulosic component present in the biomass. ${ }^{44}$ Low-intensity bands around $2915 \mathrm{~cm}^{-1}$ were also observed, which may indicate the presence of $\mathrm{C}-\mathrm{H}$ stretch of the $\mathrm{CH}_{2}$ group relative to the lipid component of the sample, in addition to being an indicative of the presence of lignin. The band appearing at $1617 \mathrm{~cm}^{-1}$ is characteristic of vibrational carbonyl stretches (stretching of $\mathrm{C}=\mathrm{O}$ in COO-). ${ }^{22,45}$ In the case of the study sample, it is possible that the said band refers to the stretching vibrations of the $\mathrm{C}=\mathrm{O}$ bond of carbonyl, which is part of the structure of the proteins and fatty acids of the lipid fraction. It is possible to observe the presence of low intensity bands in the region 1430-1360 $\mathrm{cm}^{-1}$, which is an indication of the presence of angular deformation in the plane of the $\mathrm{O}-\mathrm{H}$ bond. Therefore, the presence of phenol is represented by the near $1370 \mathrm{~cm}^{-1}$ band that can be related to $\operatorname{Ar}(\mathrm{OH}){ }^{22,46}$ The band at $1370 \mathrm{~cm}^{-1}$ can be assigned to the presence of $\mathrm{CH}$ bonds in cellulose and hemicellulose. ${ }^{44}$ The absorptions 
at 1260 and $1230 \mathrm{~cm}^{-1}$ can be assigned to the $\mathrm{C}-\mathrm{O}$ stretch of phenol. ${ }^{46}$ The relatively broad band appearing at $1030 \mathrm{~cm}^{-1}$ can be assigned to the stretching of the $\mathrm{C}-\mathrm{O}$ bond of alcoholic groups. ${ }^{47,48}$ It can also be assigned to the presence of stretches of $\mathrm{C}-\mathrm{O}$ bond in lignocellulosic compounds. ${ }^{44}$ Not only does this band justify the high total carbohydrate content, evidenced in the chemical composition, but also the presence of lignin in the biomass. Considering the vibrational modes of the $-\mathrm{OH},-\mathrm{COOH}$ and $-\mathrm{NH}_{2}$ groups, it is possible to suggest that $\mathrm{Cr}^{\mathrm{VI}}$ can be adsorbed through electrostatic attractions.

The FTIR spectrum of the BMC obtained after the chromium adsorption process, evidenced that the leading bands are preserved. However, some perturbations, such as the decrease in transmittance and change in wavenumber were perceived. These perturbations can be attributed to the interaction of the metal with the adsorbent. A close analysis of the two spectra allows to verify that the bands around 3300,1620 and $1030 \mathrm{~cm}^{-1}$ in the biomass after the adsorption had a decrease in transmittance, concerning the biomass before adsorption. The band at $3344 \mathrm{~cm}^{-1}$ shifted to a lower frequency $\left(3339 \mathrm{~cm}^{-1}\right)$, while the band at $1617 \mathrm{~cm}^{-1}$ shifted to a higher frequency $\left(1634 \mathrm{~cm}^{-1}\right)$. Similar results have been reported in previous studies, ${ }^{48-52}$ in which changes in vibrational frequencies, decrease and banding were verified. These changes are an evidence of $\mathrm{Cr}^{\mathrm{VI}}$ adsorption in aqueous media through functional groups present in the biomass structure.

Thermal analysis: thermogravimetric (TG) analysis and differential thermal analysis

According to the TG result, it was possible to verify that the BMC exhibited three stages of mass loss. The first stage occurred at a temperature of 100 to $150{ }^{\circ} \mathrm{C}$ and may be assigned to water loss. This result is consistent with the biomass moisture content of $9.150 \%$. The second stage of mass loss was observed in the $220-380{ }^{\circ} \mathrm{C}$ range and can be assigned to the decomposition of the organic extractives present in the biomass. The third stage of decomposition occurred between 380 and $600{ }^{\circ} \mathrm{C}$. This third mass loss event can be associated with the thermal degradation of cellulose, hemicellulose, and lignin, leading to the production of coal. Above $650^{\circ} \mathrm{C}$, the mass loss curve did not exhibit any other thermal events, indicating the thermal stability of the carbonaceous structure formed.

The DTA curve showed a discrete endothermic peak around $80{ }^{\circ} \mathrm{C}$, confirming the exit of water signaled by the mass loss in the TG curve. This behavior confirms the low humidity of the BMC. An endothermic peak around $350-380{ }^{\circ} \mathrm{C}$ was also observed, which can be assigned to the release of volatiles from the decomposition of organic compounds. There was also a weak exothermic peak at $450{ }^{\circ} \mathrm{C}$ and a sharp exothermic peak at $500{ }^{\circ} \mathrm{C}$, which may be associated with the combustion of cellulose, hemicellulose and lignin.

\section{Point of zero charge (PZC) and suspended $\mathrm{pH}$}

The results obtained for $\mathrm{PZC}$ and suspended $\mathrm{pH}$ indicate that $\mathrm{BMC}$ has a $\mathrm{pH}$ close to neutrality, considering that these results were approximately 6.50. In the case of PZC, this data indicates that when the solution is maintained at $\mathrm{pH}$ lower than the zero charge $\mathrm{pH}\left(\mathrm{pH}_{\mathrm{PZC}}\right)$ of the biomass, the protonation of specific functional groups occurs, and the biomass behaves like a positively charged matrix, attracting negatively charged ions present in solution..$^{25} \mathrm{On}$ the other hand, when the $\mathrm{pH}$ value of the solution increases and the $\mathrm{pH}$ is higher than $\mathrm{pH}_{\mathrm{PZC}}$, the surface charge of the adsorbent is negative, and cation binding is favored, ${ }^{7}$ since there is deprotonation of active functional groups on the biomass surface.

\section{Adsorption studies}

\section{Mass of BMC}

The result for the effect of the mass of $\mathrm{BMC}$ on $\mathrm{Cr}^{\mathrm{VI}}$ adsorption is shown in Figure 2.

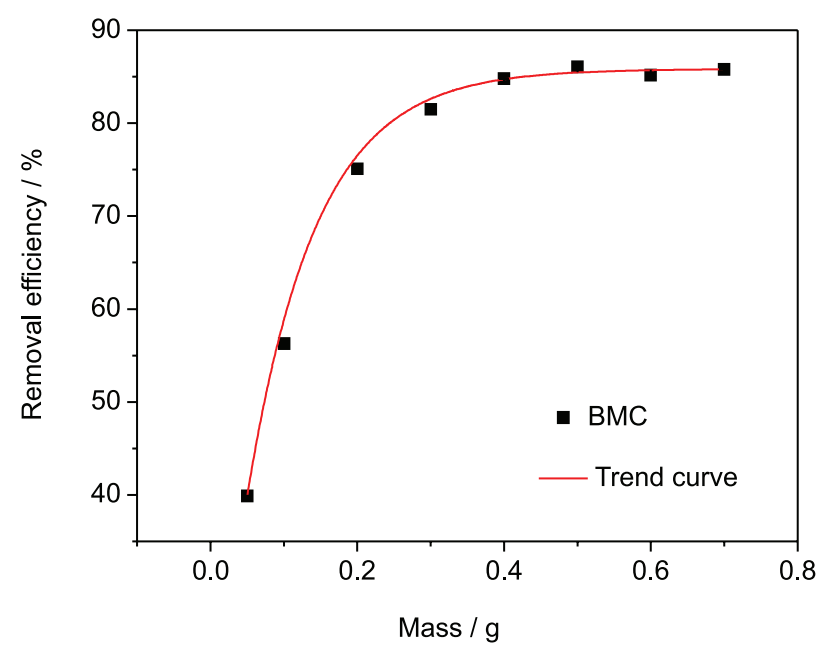

Figure 2. Adsorption of $\mathrm{Cr}^{\mathrm{VI}}$ on $\mathrm{BMC}$ as a function of adsorbent dosage $(298 \mathrm{~K}$, initial $\mathrm{pH}=2.5)$.

From the results of the mass study, it was possible to verify that $\mathrm{Cr}^{\mathrm{VI}}$ removal has a sharp increase up to 0.30 when it reaches about $80 \%$ removal. After this point, adsorption capacity does not vary significantly, reaching equilibrium. With the lowest mass, the number of active sites available for the interaction between adsorbate and adsorbent is small, which explains the low removal of the metal. By increasing the mass of the BMC, the availability 
of active sites also increases, thus yielding better efficiency in the adsorption process. ${ }^{9,10,52}$

The maximum adsorption point of $\mathrm{Cr}^{\mathrm{VI}}$, approximately $85 \%$, was reached with a mass of approximately $0.4000 \mathrm{~g}$, indicating that the metal occupied the available sites in the biomass structure. For later studies, the adopted mass was $0.4500 \mathrm{~g}$, considering that, from this point, the system reached equilibrium and there was no significant increase in metal removal.

\section{Effect of $\mathrm{pH}$ on $\mathrm{Cr}^{\mathrm{vl}}$ adsorption}

One of the most critical parameters in the removal processes of metals present in an aqueous medium through adsorption is $\mathrm{pH}$. The variation in $\mathrm{pH}$ can affect the characteristics and the availability of metallic ions in solution, as well as modify the chemical state of the functional groups responsible for the interactions. ${ }^{7}$ To better understand such behavior, it is essential to remember that $\mathrm{Cr}^{\mathrm{VI}}$ chemistry is very $\mathrm{pH}$-dependent and the $\mathrm{HCrO}_{4}^{-}$ion is the main hexavalent chromium species present at low $\mathrm{pH} .{ }^{21}$ Figure 3 shows the effect of $\mathrm{pH}$ on $\mathrm{Cr}^{\mathrm{VI}}$ adsorption.

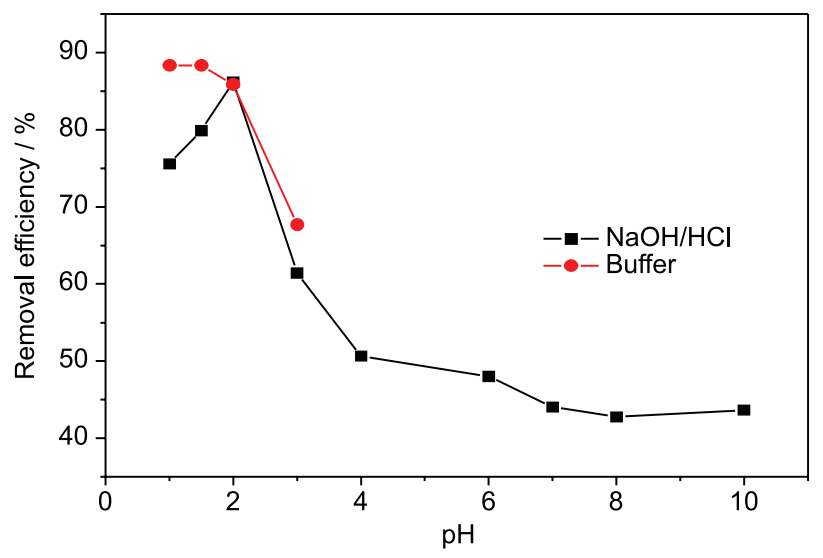

Figure 3. Effect of initial $\mathrm{pH}$ on the adsorption of $\mathrm{Cr}^{\mathrm{VI}}$.

It can be inferred from Figure 3 that the adsorption process in the system under study was favored at low $\mathrm{pH}$, specifically between 1.5 and 2.0, where the maximum amount removed was $2.40 \mathrm{mg} \mathrm{g}^{-1}$ (metal removal of approximately 90\%). Above $\mathrm{pH} 2$, a decline in removal efficiency was noted, with the amount removed below $1.40 \mathrm{mg} \mathrm{g}^{-1}$. According to information reported in the literature, ${ }^{7,10,14,18,19}$ it was verified that the best $\mathrm{pH}$ value found in this study is in agreement with the results obtained by other researchers when using biomass for $\mathrm{Cr}^{\mathrm{VI}}$ removal.

Considering the results of infrared spectroscopy (Figure 1), the presence of $-\mathrm{OH},-\mathrm{COOH}$ and $\mathrm{NH}_{2}$ groups, which are considered as active sites, ${ }^{52}$ may be responsible for the electrostatic attraction of positive species in solution. On the other hand, at low $\mathrm{pH}$, there is an excellent availability of $\mathrm{H}_{3} \mathrm{O}^{+}$ions in solution that protonate these groups and, therefore, the attraction of $\mathrm{Cr}^{\mathrm{VI}}$ oxyanion (in aqueous solution, low $\mathrm{pH}$ and concentration lower than $500 \mathrm{mg} \mathrm{L}^{-1}$, the $\mathrm{HCrO}_{4}^{-}$ion predominates), is favored. ${ }^{53}$ As $\mathrm{pH}$ increases, the protonation of the groups present on the surface of the biomass (forming electrophilic centers) is less intense, which explains the decrease in adsorption, as can be seen in Figure 3. Thus, adsorption is not favored in alkaline $\mathrm{pH}$ as a function of the repulsion between the metal species and the active functional groups of the biomass. Therefore, $\mathrm{pH} 2.0$ was considered the best and was used for subsequent studies.

The result obtained for the $\mathrm{pH}$ effect ratifies the result of $\mathrm{pH}_{\mathrm{PZC}}$, which describes that, at $\mathrm{pH}$ values below 6.50, the protonation of specific functional groups occurs and biomass behaves as a positively charged matrix, attracting the negatively charged ions present in solution, which yielded the removal of $\mathrm{Cr}^{\mathrm{VI}}$ species.

\section{Adsorption kinetics and equilibrium}

The adsorption kinetics of $\mathrm{Cr}^{\mathrm{VI}}$ on $\mathrm{BMC}$ is shown in Figure 4, in which the effects of the nature of the adsorbent BMC and its adsorption metal capacity can be observed. The $\mathrm{Cr}^{\mathrm{VI}}$ removal rate is $80 \%$ in the first $10 \mathrm{~min}$ of adsorption at the most readily available active sites on the surface of the adsorbent, ${ }^{53}$ but equilibrium is reached after $80 \mathrm{~min}$, suggesting the existence of active sites on the inner surface of the BMC. ${ }^{17,18}$

The kinetic data were fitted to the non-linear kinetic models of pseudo-first order, pseudo-second order, and Elovich. The results are presented in Figure 4 and Table 4.

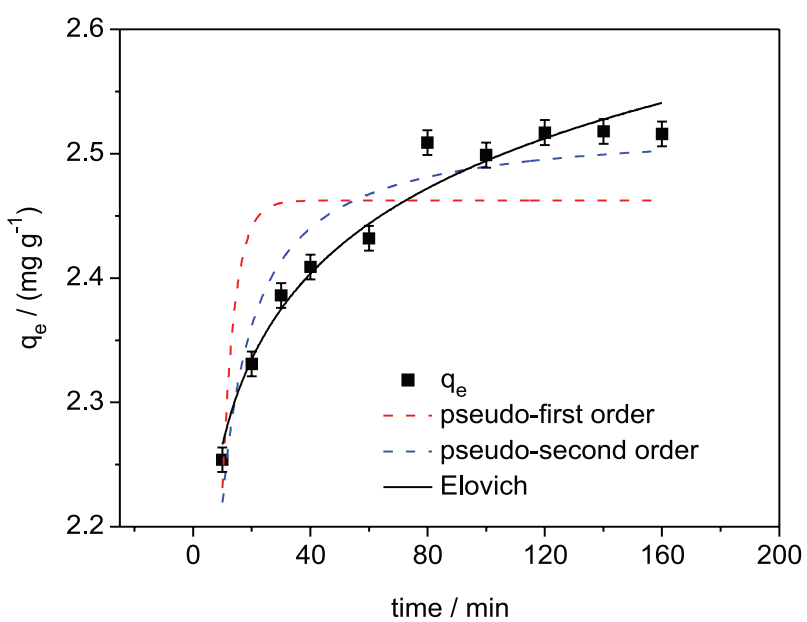

Figure 4. Nonlinear fit of $\mathrm{Cr}^{\mathrm{VI}}$ adsorption data on $\mathrm{BMC}$ adsorbent (mass $=0.45 \mathrm{~g}$, initial $\mathrm{pH}=2.0$ ).

According to Table $4, \mathrm{R}^{2}$ values suggest that the data were better suited to the pseudo-second-order models $\left(\mathrm{R}^{2}=0.897\right)$ and the Elovich model $\left(\mathrm{R}^{2}=0.962\right)$. When the function $\chi^{2}$ 
Table 4. Kinetic parameters for $\mathrm{Cr}^{\mathrm{VI}}$ adsorption on $\mathrm{BMC}$ using different models

\begin{tabular}{lcc}
\hline Kinetic model & Parameter & BMC $^{\mathrm{a}}$ \\
\hline \multirow{4}{*}{ Pseudo-first order } & $\mathrm{q}_{\mathrm{m}} /\left(\mathrm{mg} \mathrm{g}^{-1}\right)$ & 2.46 \\
& $\mathrm{~K}_{\mathrm{S} 1} / \mathrm{min}^{-1}$ & 0.237 \\
& $\mathrm{R}^{2}$ & 0.495 \\
& $\chi^{2}$ & 0.0043 \\
\hline \multirow{2}{*}{ Pseudo-second order } & $\mathrm{q}_{\mathrm{m}} /\left(\mathrm{mg} \mathrm{g}^{-1}\right)$ & 2.52 \\
& $\mathrm{~K}_{\mathrm{S} 2} /\left(\mathrm{g} \mathrm{mg}^{-1} \mathrm{~min}^{-1}\right)$ & 0.289 \\
& $\mathrm{R}^{2}$ & 0.897 \\
& $\chi^{2}$ & $8.73 \times 10^{-4}$ \\
\hline \multirow{3}{*}{ Elovich } & $\mathrm{b} /\left(\mathrm{mg} \mathrm{mg}^{-1} \mathrm{~min}^{-1}\right)$ & $8.54 \times 10^{7}$ \\
& $\mathrm{R}^{2}$ & 10.10 \\
$\chi^{2}$ & 0.962 \\
\hline
\end{tabular}

${ }^{a}$ Adsorbent from the yellow mombin seeds. $\mathrm{q}_{\mathrm{m}}$ : maximum sorption capacity of the biosorbent; $\mathrm{K}_{\mathrm{S} 1}$ : Lagergren rate constant of the first sorption; $\mathrm{K}_{\mathrm{s} 2}$ : adsorption rate constant; $\mathrm{R}^{2}$ : coefficient of determination; $\chi^{2}$ : Chi-square statistic test for determination of a non-linear model; a and b: initial sorption rate and desorption constant, respectively.

was used as a measure of comparison, the result indicates that the Elovich model better describes $\mathrm{Cr}^{\mathrm{VI}}$ adsorption on BMC. In fact, the constants a and $b$ represent a suitable combination involving valence forces through the sharing or exchange of electrons between the adsorbent and the adsorbate, suggesting chemisorption as the predominant mechanism, in addition to the Elovich model being considered adequate to describe the adsorption process on heterogeneous surfaces. ${ }^{54}$ Similar results were found in the literature. ${ }^{19,55,56}$

The adsorption isotherms were adjusted using the Langmuir, Freundlich, and Redlich-Peterson non-linear models (Figure 5), and the parameters are shown in Table 3. It can be observed that, regardless of the number of isothermal parameters, the data were well adjusted for all three models. This result confirms that the Langmuir, Freundlich, and Redlich-Peterson models are relevant to describe the equilibrium established between $\mathrm{Cr}^{\mathrm{VI}}$ adsorbed ions and $\mathrm{Cr}^{\mathrm{VI}}$ ions remaining in solution. ${ }^{21}$

When the correlation factors $\mathrm{R}^{2}$ and values of $\chi^{2}$ are compared between the three models, they are very close, as shown in Table $5\left(R^{2}=0.983\right.$ for Langmuir, $R^{2}=0.985$ for the Freundlich model and $\mathrm{R}^{2}=0.984$ for Redlich-Peterson), indicating that any of the models can be used to describe chromium(VI) adsorption through BMC. In an attempt to define more precisely which of the models best fits the equilibrium data, the error functions sum of squared errors (SSE); average relative error (ARE) and hybrid fractional error function (HYBRID) were used, as can be observed in Table 6.

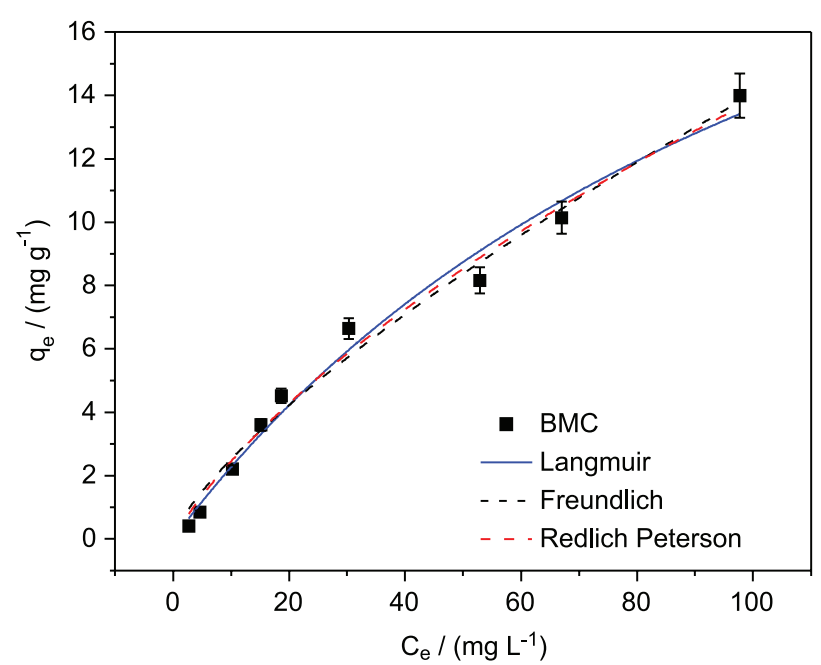

Figure 5. Adsorption isotherms of $\mathrm{Cr}^{\mathrm{VI}}$ on $\mathrm{BMC}$ and adjustments using Langmuir, Freundlich, and Redlich-Peterson models.

Table 5. Langmuir, Freundlich, and Redlich-Peterson isotherm parameters in the $\mathrm{Cr}^{\mathrm{VI}}$ adsorption by using BMC

\begin{tabular}{lcc}
\hline Isotherm & Parameter & Value \\
\hline \multirow{4}{*}{ Langmuir } & $\mathrm{q}_{\mathrm{m}} /\left(\mathrm{mg} \mathrm{g}^{-1}\right)$ & 30.543 \\
& $\mathrm{~K}_{\mathrm{L}} /\left(\mathrm{L} \mathrm{mg}^{-1}\right)$ & 0.008 \\
$\mathrm{R}^{2}$ & 0.983 \\
$\chi^{2}$ & 0.349 \\
\hline \multirow{3}{*}{ Freundlich } & $\mathrm{K}_{\mathrm{F}} /\left(\mathrm{mg} \mathrm{g}^{-1}\right)\left(\mathrm{L} \mathrm{g}^{-1}\right)^{\mathrm{n}}$ & 0.450 \\
& $\mathrm{n}$ & 1.338 \\
& $\mathrm{R}^{2}$ & 0.985 \\
$\chi^{2}$ & 0.318 \\
\hline \multirow{3}{*}{ Redlich-Peterson } & $\mathrm{K}_{\mathrm{R}} /\left(\mathrm{L} \mathrm{g}^{-1}\right)$ & 0.366 \\
$\mathrm{a}_{\mathrm{R}} / \mathrm{mg}^{-1}$ & 0.149 \\
$\mathrm{~g}^{2}$ & 0.521 \\
$\mathrm{R}^{2}$ & 0.984 \\
$\chi^{2}$ & 0.333 \\
\hline
\end{tabular}

$\mathrm{q}_{\mathrm{m}}$ : maximum sorption capacity of the adsorbent; $\mathrm{K}_{\mathrm{L}}$ : Langmuir constant; $\mathrm{K}_{\mathrm{F}}$ and $\mathrm{n}$ : Freundlich constant; $\mathrm{K}_{\mathrm{R}}$, $\mathrm{g}$ and $\mathrm{a}_{\mathrm{R}}$ : Redlich-Peterson isotherm constants; $\mathrm{R}^{2}$ : coefficient of determination; $\chi^{2}$ : Chi-square statistic test for determination of a non-linear model.

Table 6. Comparison of isotherm models using error functions

\begin{tabular}{lccc}
\hline \multirow{2}{*}{ Model } & \multicolumn{3}{c}{ Error functions } \\
\cline { 2 - 4 } & SSE & ARE & HYBRID \\
\hline Langmuir & 2.451 & 15.324 & 7.534 \\
Freundlich & 2.228 & 28.101 & 19.522 \\
Redlich-Peterson & 1.996 & 21.649 & 13.810 \\
\hline
\end{tabular}

SSE: sum of squared error; ARE: average relative error; HYBRID: hybrid fractional error function.

The values presented by the error functions ARE and HYBRID in Table 6 indicate that the equilibrium data fits 
the Langmuir model. The advantage of using these functions is in minimizing the fractional distribution of errors over the entire concentration range..$^{27}$ This result corroborates the FTIR results (Figure 1), which indicates the adsorption in specific sites, but does not exclude the occurrence of the chemisorption indicated by the Freundlich model, since the transport phenomena and chemical reactions occur simultaneously in real systems. ${ }^{54}$

\section{Study of the initial concentration of the metal solution}

The performance of $\mathrm{BMC}$ in $\mathrm{Cr}^{\mathrm{VI}}$ removal can also be evaluated as a function of the initial concentration of the solution containing the metal and the removal efficiency at the time of equilibrium (Figure 6).

The results show that the removal efficiency of the metal decreased significantly with the increase in the initial concentration of the solution, and $98 \%$ removal was achieved at a concentration of $10 \mathrm{mg} \mathrm{L}^{-1} \mathrm{Cr}^{\mathrm{VI}}$. As the saturation of the sites available for adsorption occurs, an increase in the adsorbed amount was observed but, naturally, the effect on the removal percentage is inverse. ${ }^{13}$ However, efficiency remains high, removal $>85 \%$, even when the initial concentration reaches $100 \mathrm{mg} \mathrm{L}^{-1}$. This

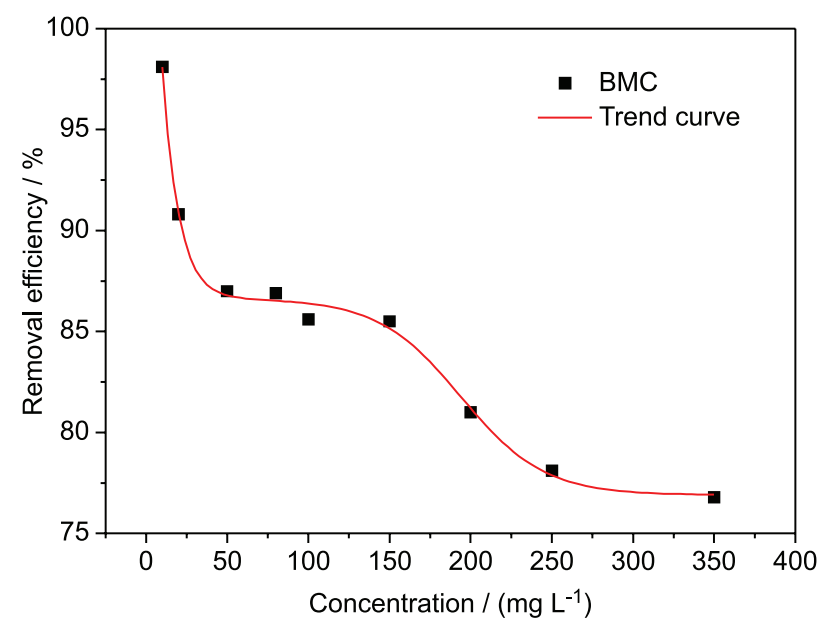

Figure 6. Effect of initial concentration (condition: amount of adsorbent $0.45 \mathrm{~g}$; pH 2.0; contact time $120 \mathrm{~min}$ ).

means that, from the environmental point of view, the $\mathrm{BMC}$ is a promising alternative in the remediation of $\mathrm{Cr}^{\mathrm{VI}}$ contaminated effluents. The same behavior was obtained by other researchers when using different natural adsorbents for metal adsorption. . $^{9,3,57}$

Table 7 shows a summary of some studies used in the adsorption of chromium in aqueous solutions. These have been recently published not only on the use of natural

Table 7. Comparison of the adsorption capacity of some adsorbents for removal of chromium $\mathrm{Cr}^{\mathrm{vI}}$

\begin{tabular}{|c|c|c|c|c|c|}
\hline Adsorbent & Pre-treatment & $\mathrm{pH}$ & time / min & Removal / \% & Reference \\
\hline $\begin{array}{l}\text { Activated carbon-apple } \\
\text { peels }\end{array}$ & $\begin{array}{c}\text { concentrated phosphoric acid }\left(85 \% \mathrm{H}_{3} \mathrm{PO}_{4}\right) \text { in } 2.7: 1 \text { ratio }\left(\mathrm{H}_{3} \mathrm{PO}_{4} \text { volume }\right. \\
(\mathrm{mL}) / \text { dried apple peels mass }(\mathrm{g})) \text { and activated in a muffle furnace } \\
\text { maintained at } 619^{\circ} \mathrm{C} \text { for } 56 \text { min }\end{array}$ & 2.0 & 120 & 95 & 58 \\
\hline $\begin{array}{l}\text { Treated waste } \\
\text { newspaper }\end{array}$ & $\begin{array}{c}\text { concentrated sodium bicarbonate solution for removing foreign materials } \\
\text { then refluxed with } 5.0 \% \mathrm{Na}_{2} \mathrm{HPO}_{4} \text { using a water condenser for } 3 \mathrm{~h} \text { to } \\
\text { impregnate the phosphate into the cellulose matrix }\end{array}$ & 3.0 & 60 & 64 & 59 \\
\hline $\begin{array}{l}\text { Immobilized } \\
\text { Zea mays biomass }\end{array}$ & $\begin{array}{l}\text { for immobilization procedure, Na-alginate }(2 \%, \mathrm{~m} / \mathrm{v}) \text { was dissolved in hot } \\
\text { water }\left(60^{\circ} \mathrm{C}\right) \text { and } 1 \mathrm{~g} \text { of corn cob powder was added and homogenized by } \\
\text { agitation and extruded into } 0.1 \mathrm{M} \mathrm{CaCl}_{2} \text { solution }\end{array}$ & 2.0 & 240 & 56 & 60 \\
\hline $\begin{array}{l}\text { Modified groundnut } \\
\text { hull }\end{array}$ & $\begin{array}{l}\text { after appropriate washing and drying steps, portions of the groundnut hull } \\
\text { were then modified with pyromellitic dianhydride (PMDA) }\end{array}$ & 2.0 & 60 & $>95$ & 61 \\
\hline $\begin{array}{l}\text { Biosorbent from } \\
\text { mango leaves }\end{array}$ & $\begin{array}{l}\text { the leave dust was washed with deionized water and the soluble colored } \\
\text { components were then removed by washing repeatedly with hot deionized } \\
\text { water }\left(70^{\circ} \mathrm{C}\right) \text {. Then, was then dried at } 70^{\circ} \mathrm{C} \text { for } 24 \mathrm{~h}\end{array}$ & 2.0 & 120 & 91 & 62 \\
\hline $\begin{array}{l}\text { Biosorbent from } \\
\text { peppermint leaves }\end{array}$ & $\begin{array}{l}\text { drying at room temperature away from sunlight, ground and then sieved to } \\
\text { appropriate particle size }\end{array}$ & 2.0 & 180 & 95 & 63 \\
\hline $\begin{array}{l}\text { Almond green hull } \\
\text { waste material }\end{array}$ & $\begin{array}{c}\text { the sorbent was washed thoroughly several times with deionized water and } \\
\text { was dried at room temperature for some days } \\
\text { then, the dried sample was powdered and sieved }\end{array}$ & 2.0 & 60 & $>99$ & 64 \\
\hline $\begin{array}{l}\text { Mixed biosorbent } \\
\text { (Pseudomonas stutzeri } \\
\text { and acid treated } \\
\text { Banyan tree bark) }\end{array}$ & $\begin{array}{l}\text { the materials were rinsed, air-dried, ground into fine particles and then } \\
\text { sulfuric acid was added in the ratio } 1: 2 \text { and left undisturbed for } 24 \mathrm{~h} \\
\text { the materials were then heated up to } 80^{\circ} \mathrm{C} \text { for } 30 \mathrm{~min}\end{array}$ & 2.0 & 45 & 95 & 12 \\
\hline Water caltrop shell & $\begin{array}{l}\text { the material was rinsed with distilled water and was dried at } 48^{\circ} \mathrm{C} \text { in hot } \\
\text { air oven for } 48 \mathrm{~h} \\
\text { then, the dried shells were ground to powder and sieved to obtain particles } \\
\text { of different sizes }\end{array}$ & 2.0 & 60 & 90 & 65 \\
\hline $\begin{array}{l}\text { Biosorbent from } \\
\text { yellow mombin seeds }\end{array}$ & $\begin{array}{l}\text { after washing and drying steps in the sun, the material was dried in a stove } \\
\text { with air circulation for } 24 \mathrm{~h} \text { and ground in a 2-mm opening knife mill }\end{array}$ & 2.0 & 120 & 98 & this study \\
\hline
\end{tabular}


adsorbent, but on activated carbon and chemically treated residues. In comparison with previous studies, the new adsorbent obtained in this research showed better results than some of the highlighted adsorbent materials, including some that received physical or chemical treatment. Considering the adsorbents with better results, it was observed that the BMC presented a similar performance, indicating that this material could become a promising low cost and eco-friendly alternative.

\section{Conclusions}

The adsorbent BMC was obtained by a simple methodology using biomass of yellow mombin seeds from agro-industrial residues and it is efficient in the removal of hexavalent chromium in the aqueous medium. The material presented vibrational modes characteristic of functional groups $-\mathrm{OH},-\mathrm{COOH}$ and $-\mathrm{NH}_{2}$, responsible for the electrostatic attraction of negative species when in acidic $\mathrm{pH}$. BMC also showed values for PZC and suspended $\mathrm{pH}$ around 6.50. Such characteristics led to a 98\% removal of the hexavalent chromium present in the solution. The studied system was kinetically modeled through the pseudo-first-order, pseudo-second order, and Elovich models. The kinetic data were better suited to the Elovich model used to describe the adsorption process on heterogeneous surfaces. The equilibrium data were adjusted to the Langmuir, Freundlich and Redlich-Peterson models and the results showed that the three models are relevant to describe the equilibrium established between $\mathrm{Cr}^{\mathrm{VI}}$ adsorbed ions and $\mathrm{Cr}^{\mathrm{VI}}$ ions remaining in solution. Rapid removal of adsorbate and reaching equilibrium in a short period of time, in addition to the fact that no physical or chemical treatment has been used, indicate that BMC can be a promising alternative for decontamination of aqueous systems. The outcomes from this research study indicated the solution to two environmental problems. On the one hand, the reuse an agro-industrial waste that would be discarded in the environment and, on the other hand, the production of a low-cost and eco-friendly adsorbent.

\section{Acknowledgments}

This study was financed in part by the Coordenação de Aperfeiçoamento de Pessoal de Nível Superior-Brasil (CAPES), finance code 001. The authors also acknowledge the financial support of the Conselho Nacional de Desenvolvimento Científico e Tecnológico (311419/2018-6) and the Financiadora de Estudos e Projetos (FINEP).

\section{References}

1. Burakov, A. E.; Galunin, E. V.; Burakova, I. V.; Kucherova, A. E.; Agarwal, S.; Tkachev, A. G.; Gupta, V. K.; Ecotoxicol. Environ. Saf. 2018, 148, 702.

2. Saravanan, A.; Kumar, P. S.; Carolin, C. F.; Sivanesan, S.; J. Hazard., Toxic Radioact. Waste 2017, 21, 04017004.

3. de Rossi, A.; Rigon, M. R.; Zaparoli, M.; Braido, R. D.; Colla, L. M.; Dotto, G. L.; Piccin, J. S.; Environ. Sci. Pollut. Res. 2018 , 25, 19179.

4. Saravanan, A.; Kumar, P. S.; Yaswanthraj, M.; Part. Sci. Technol. 2018, 36, 934.

5. Carolin, C. F.; Kumar, P. S.; Saravanan, A.; Joshiba, G. J.; Naushad, M.; J. Environ. Chem. Eng. 2017, 5, 2782.

6. Yaashikaa, P. R.; Kumar, P. S.; Varjani, S. J.; Saravanan, A.; Environ. Sci. Pollut. Res. 2019, 292, 122030.

7. Blázquez, G.; Hernáinz, F.; Calero, M.; Martín-Lara, M. A.; Tenorio, G.; Chem. Eng. J. 2009, 148, 473.

8. Bulut, Y.; Baysal, Z.; J. Environ. Manage. 2006, 78, 107.

9. Javadian, H.; Ahmadi, M.; Ghiasvand, M.; Kahrizi, S.; Katal, R.; J. Taiwan Inst. Chem. Eng. 2013, 44, 977.

10. Saha, R.; Mukherjee, K.; Saha, I.; Ghosh, A.; Ghosh, S. K.; Saha, B.; Res. Chem. Intermed. 2013, 39, 2245.

11. Wang, X. S.; Li, Z. Z.; Sun, C.; J. Hazard. Mater. 2008, 153, 1176.

12. Yaashikaa, P.; Kumar, P. S.; Babu, V. M.; Durga, R. K.; Manivasagan, V.; Saranya, K.; Saravanan, A.; J. Mol. Liq. 2019, 276, 362.

13. Nguyen, T. A.; Ngo, H. H.; Guo, W. S.; Zhang, J.; Liang, S.; Yue, Q. Y.; Li, Q.; Nguyen, T. V.; Bioresour. Technol. 2013, 148, 574.

14. Dakiky, M.; Khamis, M.; Manassra, A.; Mer'eb, M.; Adv. Environ. Res. 2002, 6, 533.

15. Sharma, D. C.; Forster, C. F.; Bioresour. Technol. 1995, 52, 261.

16. Zhang, L.; Niu, W.; Sun, J.; Zhou, Q.; Chemosphere 2020, 248 , 126102.

17. Barakat, M. A.; Arabian J. Chem. 2011, 4, 361.

18. Chand, R.; Narimura, K.; Kawakita, H.; Ohto, K.; Watari, T.; Inoue, K.; J. Hazard. Mater. 2009, 163, 245.

19. Demiral, H.; Demiral, İ.; Tümsek, F.; Karabacakoğlu, B.; Chem. Eng. J. 2008, 144, 188.

20. Dubey, S. P.; Gopal, K.; J. Hazard. Mater. 2007, 145, 465.

21. Sun, Y.; Yue, Q.; Gao, B.; Gao, Y.; Li, Q.; Wang, Y.; Chem. Eng. J. 2013, 217, 240.

22. Varga, M.; Takács, M.; Záray, G.; Varga, I.; Microchem. J. 2013, 107, 25.

23. Sud, D.; Mahajan, G.; Kaur, M. P.; Bioresour. Technol. 2008, 99, 6017.

24. Bajpai, A.; Rajpoot, M.; J. Sci. Ind. Res. 1999, 58, 844.

25. Farooq, U.; Kozinski, J. A.; Khan, M. A.; Athar, M.; Bioresour. Technol. 2010, 101, 5043. 
26. Liu, Z.; Zhou, X.; Chen, X.; Dai, C.; Zhang, J.; Zhang, Y.; J. Environ. Sci. 2013, 25, 2384.

27. Foo, K. Y.; Hameed, B. H.; Chem. Eng. J. 2010, 156, 2.

28. Castro, A. M.; Pereira Jr., N.; Quim. Nova 2010, 33, 181.

29. Gupta, V.; Carrott, P.; Singh, R.; Chaudhary, M.; Kushwaha, S.; Bioresour. Technol. 2016, 216, 1066.

30. Gupta, V. K.; Nayak, A.; Agarwal, S.; Gupta, V. K.; Nayak, A.; Agarwal, S.; Environ. Eng. Res. 2015, 20, 1.

31. Hu, Z.; Srinivasan, M. P.; Microporous Mesoporous Mater. 1999, 27, 11.

32. Lua, A. C.; Guo, J.; Colloids Surf., A 2001, 179, 151.

33. Tsai, W. T.; Chang, C. Y.; Lin, M. C.; Chien, S. F.; Sun, H. F.; Hsieh, M. F.; Chemosphere 2001, 45, 51.

34. Bligh, E. G.; Dyer, W. J.; Can. J. Biochem. Physiol. 1959, 37, 911.

35. Lutz, I. A.; Normas Analíticas: Métodos Físico-Químicos para Análise de Alimentos; Instituto Adolfo Lutz: São Paulo, 2004.

36. https://amrel.bioe.uic.edu/NSFREU2004/Reports2004/ Jaime\%20Robles_Final\%20Report.pdf, accessed in September 2020.

37. JIS K 1474: Test Methods for Activated Carbon, Japanese Standards Association: Tokyo, 1992.

38. Wang, Y.; Wang, X. J.; Liu, M.; Wang, X.; Wu, Z.; Yang, L. Z.; Xia, S. Q.; Zhao, J. F.; Ind. Crops Prod. 2012, 39, 81.

39. Alves, M. A. P. M. S.; Silva, S. C.; Silva, S. Y. S.; Pereira Jr., J. B.; Marinho, P. S. B.; Dantas, K. G. F.; da Mota, S. A. P.; Amaral, J. C.; da Silva, M. F. G. F.; Oliveira, M. N.; J. Braz. Chem. Soc. 2020, 31, 574.

40. Ho, Y.-S.; J. Hazard. Mater. 2006, 136, 681.

41. Mohammadi, S. Z.; Karimi, M. A.; Afzali, D.; Mansouri, F.; Desalination 2010, 262, 86.

42. Sen Gupta, S.; Bhattacharyya, K. G.; Adv. Colloid Interface Sci. 2011, 162, 39.

43. Karri, R. R.; Jayakumar, N. S.; Sahu, J. N.; J. Mol. Liq. 2017, 231, 249.

44. Popescu, C.-M.; Popescu, M.-C.; Singurel, G.; Vasile, C.; Argyropoulos, D.; Willför, S.; Appl. Spectrosc. 2007, 61, 1168.

45. Zhang, S.; Ji, Y.; Ao, F.; Wang, Y.; Zhao, J.; Chen, S.; J. Braz. Chem. Soc. 2018, 29, 1487.

46. Coates, J. In Encyclopedia of Analytical Chemistry; John Wiley \& Sons: Chichester, 2006, DOI: 10.1002/9780470027318. a5606.
47. Barbosa, L. C. A.; Espectroscopia no Infravermelho: na Caracterização de Compostos Orgânicos; UFV: Viçosa, 2007.

48. Kang, O. L.; Ramli, N.; Said, M.; Ahmad, M.; Yasir, S. M.; Ariff, A.; J. Environ. Sci. 2011, 23, 918.

49. Pakade, V. E.; Ntuli, T. D.; Ofomaja, A. E.; Appl. Water Sci. 2017, 7, 3015.

50. Tyagi, U.; Khandegar, V.; J. Hazard., Toxic Radioact. Waste 2018, 22, 04018014.

51. Vendruscolo, F.; Ferreira, G. L. R.; Antoniosi Filho, N. R.; Int. Biodeterior. Biodegrad. 2017, 119, 87.

52. Mahmoud, M. E.; J. Environ. Manage. 2015, 147, 264.

53. Pehlivan, E.; Kahraman, H. T.; Food Chem. 2012, 133, 1478.

54. Qiu, H.; Lv, L.; Pan, B.-c.; Zhang, Q.-j.; Zhang, W.-m.; Zhang, Q.-x.; J. Zhejiang Univ., Sci., A 2009, 10, 716.

55. Figueiredo-Sganderla, J. A.; Prodanov, C. C.; Daroit, D.; Braz. J. Biol. 2010, 70, 1231.

56. Wang, Y.; Yang, Q.; Chen, J.; Yang, J.; Zhang, Y.; Chen, Y.; Li, X.; Du, W.; Liang, A.; Ho, S.-H.; Chang, J.-S.; J. Hazard. Mater. 2020, 395, 122658.

57. Yuvaraja, G.; Krishnaiah, N.; Subbaiah, M. V.; Krishnaiah, A.; Colloids Surf., B 2014, 114, 75.

58. Enniya, I.; Rghioui, L.; Jourani, A.; Sustainable Chem. Pharm. 2018, 7, 9 .

59. Dehghani, M. H.; Sanaei, D.; Ali, I.; Bhatnagar, A.; J. Mol. Liq. 2016, 215, 671.

60. Manzoor, Q.; Sajid, A.; Hussain, T.; Iqbal, M.; Abbas, M.; Nisar, J.; J. Mater. Res. Technol. 2019, 8, 75.

61. Owalude, S. O.; Tella, A. C.; Beni-Suef Univ. J. Basic Appl. Sci. 2016, 5, 377.

62. Saha, R.; Saha, B.; Desalin. Water Treat. 2014, 52, 1928.

63. Najim, T. S.; Farhan, S. A.; Dadoosh, R. M.; Desalin. Water Treat. 2014, 52, 4810 .

64. Nasseh, N.; Taghavi, L.; Barikbin, B.; Harifi-Mood, A. R.; J. Water Reuse Desalin. 2017, 7, 449.

65. Kumar, S.; Narayanasamy, S.; Venkatesh, R. P.; Sep. Sci. Technol. 2019, 54, 2783.

Submitted: June 3, 2020

Published online: September 30, 2020 